\title{
Sociobiology
}

RESEARCH ARTICLE - ANTS

\section{Occurrence of Leaf-Cutting and Grass-Cutting Ants of the Genus Atta (Hymenoptera: Formicidae) in Geographic Regions of Brazil}

\author{
LC FORTI $^{1}$, JS RANDO ${ }^{2}$, RS CAMARGO ${ }^{1}$, AA MOREIRA ${ }^{3}$, MA CASTELLANI ${ }^{3}$, SA LEITE ${ }^{3}$, KKA SOUSA ${ }^{1}$, N CALdATO ${ }^{1}$
}

1 - Vegetal Protection Department, Laboratory of Social Insects-Pests, State University São Paulo, School of Agricultural Sciences, Botucatu, Brazil

2 - Vegetal Production Department, State University of Northern Paraná, Campus Luiz Meneghel, Bandeirantes, Brazil

3 - Departament Crop Science and Animal Science, State University Southwestern Bahia, Vitória da Conquista, Brazil

\section{Article History \\ Edited by \\ Evandro Nascimento Silva, UEFS, Brazil \\ Received $\quad 30$ July 2020 \\ Initial acceptance 07 September 2020 \\ Final acceptance 12 October 2020 \\ Publication date 28 December 2020}

\section{Keywords}

Attini, Brazilian biomes, grass-cutting ants, leaf-cutting ants.

\section{Corresponding author}

Aldenise Alves Moreira

(iD) https://orcid.org/0000-0002-2362-9624 Departamento de Fitotecnia e Zootecnia Universidade Estadual do Sudoeste da Bahia 45083-300, Vitória da Conquista-BA, Brasil. E-Mail: aldenise.moreira@gmail.com

\begin{abstract}
Leaf-cutting ants are widely distributed in Brazil, particularly species of the genus Atta. We therefore described the occurrence of leaf-cutting and grass-cutting ant species of the genus Atta. Five routes comprising some of the main highways in the South, Southeast, Midwest, and North of Brazil were sampled, in addition to ants received from other 82 municipalities, composing 300 municipalities sampled. This is the first comprehensive study of Atta in Brazil. The following species and subespecies were found: A. laevigata, A. capiguara, A. sexdens rubropilosa, $A$. sexdens piriventris, $A$. sexdens sexdens, and $A$. cephalotes. Atta laevigata and A. capiguara were the species present in the largest number of the Brazilian municipalities sampled. Atta sexdens piriventris was only recorded in the southern region of Brazil. Atta bisphaerica presented lower expansion than A. capiguara. Atta cephalotes and Atta opaciceps are species of very restricted occurrence. Southeastern region was characterized by the occurrence of $A$. capiguara and A. laevigata. Atta laevigata exhibited a generalized pattern of occurrence in the Midwest and North. Our study contributes to a better understanding of the so far unknown occurrence of leaf-cutting and grass-cutting ants within Brazil.
\end{abstract}

\section{Introduction}

Leaf-cutting ants are known in Brazil as saúvas, the genus Atta Fabricius (tribe Attini, subfamily Myrmicinae). Atta occurs throughout the Neotropical region (Mariconi, 1970) and can cause severe losses to the forest and agricultural sector of Latin American countries (Mariconi, 1970; Fowler et al., 1989; Jaffé, 1993). However, leaf-cutting ants are ecosystem engineers as they move massive amounts of soil during nest construction and remove foliage, which may change plant composition, acting as herbivores in natural systems (Farji-Brener \& Illes, 2000; Urbas et al., 2007; Costa et al., 2008; Meyer et al., 2011; Leal et al., 2014; Stephan et al., 2015). In agricultural areas these alteration of the soil and the attack on plants led to the classification as pest insects (Fowler et al., 1989).

According to Mariconi (1970), leaf-cutting ants show a wide geographic distribution, occurring from the south of the United States (latitude $33^{\circ} \mathrm{N}$ ) to central Argentina (latitude $44^{\circ} \mathrm{S}$ ). The geographic distribution, frequency and density of Attini ants in certain habitats is related to the environmental conditions such as type of vegetation, soil type, cultivation systems, climate change (Fowler, 1983; Farji-Brener \& Ruggiero, 1994; Gusmão \& Loeck, 1999; Farji-Brener et al., 2016), among others.

According to Brandão et al. (2011), the genus Atta includes 19 species, of which nine occur in Brazil, Atta bisphaerica Forel, 1908, Atta capiguara Gonçalves, 1944, 
Atta cephalotes (Linnaeus, 1758), Atta goiana, Gonçalves, 1942, Atta laevigata (Smith, F. 1858), Atta opaciceps Borgmeier, 1939, Atta robusta Borgmeier, 1939, Atta sexdens Linnaeus, 1758 and Atta wollenweideri Forel, 1893 (Bolton et al., 2006; Delabie et al., 2011). The species $A$. sexdens comprises three subspecies, $A$. sexdens sexdens, $A$. sexdens piriventris and A. sexdens rubropilosa (Mariconi, 1970; Della Lucia et al., 1993; Bacci et al., 2009).

The available information on the distribution of leafcutting ants in Brazil is found in a dispersed and unevenly updated form (Delabie et al., 2011). For the Brazilian regions, few studies on the subject have been conducted, highlighting the pioneering works of Gonçalves (1942, 1945, 1951, 1955, 1960, 1961, 1967, 1971) and Kempf (1972), who generated a broader knowledge on the distribution of species in the different regions of Brazil, and Paula (1956) for the State of Paraná and Mariconi (1966, 1970) for the State of São Paulo. More recent are the studies developed by Loeck and Grützmacher (2001) and Grürzmacher et al. (2002), for leafcutting ants in Rio Grande do Sul and Corrêa et al. (2005) and Brito et al. (2012) for the Northeastern region, States of Alagoas and Bahia, respectively. The contributions on timely reports of the occurrence of leaf-cutting ants, such as Carvalho and Tarragô (1982) for Rio Grande do Sul, Delabie (1989) for Bahia and Souza et al. (2009) for Alagoas are also noteworthy. Some authors have compiled the existing literature on the occurrence and/or geographic distribution of leaf-cutting ants in Brazil, such as the work of Della Lucia et al. (1993), Forti and Boaretto (1997) and Delabie et al. (2011).

In general, $A$. sexdens presents the broadest geographical distribution, occurring in all regions of Brazil, followed by A. laevigata, while the other species are restricted to certain Brazilian regions or states, such as $A$. robusta, which only occurs in Rio de Janeiro (Mariconi, 1970; Della Lucia et al., 1993) and Espírito Santo (Teixeira et al., 2003). It is observed that studies on the distribution of leaf-cutting ants of the genus Atta in Brazil date from at least five decades. The objective of this study was to describe the current occurrence of leafcutting and grass-cutting ants of the genus Atta in geographic regions of Brazil.

\section{Material and Methods}

For the survey of leaf-cutting and grass-cutting ants of the genus Atta, five routes comprising some of the main highways in Brazil were sampled, beginning with the city of Botucatu, São Paulo (22 50'46”S and 48 $26^{\prime} 02^{\prime \prime} \mathrm{W}$ ). The sampling was performed in 218 municipalities of the five itineraries established: 1) Botucatu (São Paulo State) to Iepê (São Paulo State), covering 48 municipalities; 2) Ibiporã (Paraná State) to Quintana (São Paulo State), with 30 municipalities; 3) Oiapoque (Amapa State) to Santa Isabel do Pará (Para State), covering four municipalities, 4) Pirajuí (São Paulo State) to
Avaré (São Paulo State), with 83 municipalities; 5) Aparecida do Taboado (Mato Grosso Sul State) to Ivinhema (Mato Grosso Sul State), comprising 53 municipalities (Table 1). Every $100 \mathrm{~km}$, in a $500 \mathrm{~m}$ long by $50 \mathrm{~m}$ wide strip, marked at random, specimens of soldier ants were collected from the colonies found. The colonies were visually searched for and selected because of the huge size of their nests (large amount of loose soil removed). We selected the municipalities nearest to the main roads. At each sampling site, at least five exemplars of the ants found on the nests or on the foraging trails were collected. All material collected at each sampling site was stored in glass flasks containing $70 \%$ alcohol and labeled with the data obtained for subsequent analysis. Latitude and longitude of the sampling municipalities were obtained with a global positioning system (Sony GPS - 360), whenever possible. After each trip, all material collected was sent to the Laboratory of Social Insect Pests (LISP) at FCA/UNESP, Botucatu, SP.

In addition to the collections made in routes, biological material from other 82 municipalities in different regions of Brazil were duly collected and sent for identification, making up the total of 300 sampled municipalities (Table 2).

After screening, the specimens were mounted and identified under a stereo microscope based on the data published by Gonçalves (1961) and using the identification keys of Borgmeier (1959) and Mariconi (1970). For Atta sexdens, the division into subspecies according to Bacci et al. (2009) was considered. All material obtained was compared with specimens stored in the Museum of Zoology, University of São Paulo, and in the Ângelo Moreira da Costa Lima Entomology Collection of Universidade Federal Rural do Rio de Janeiro. The material of this study was stored in Museum of Zoology, University of São Paulo.

\section{Results}

Considering the 300 sampled municipalities (Table 3), frequency of leaf-cutting ant species are: Atta laevigata $(32.6 \%)$, A. capiguara (20.0\%), A. sexdens rubropilosa (10.0\%), A. sexdens piriventris (9.7\%), A. sexdens sexdens $(2.7 \%), A$. cephalotes (1.6\%), A. opaciceps (0.3\%), A. bisphaerica $(0.3 \%)$, and $A$. vollenweideri $(0.3 \%)$. Our results showed that Atta laevigata and A. capiguara were the species present in the largest number of the sampled municipalities (Fig 1); Atta sexdens piriventris was only recorded in the South region of Brazil, with predominance in the states of Santa Catarina and Rio Grande do Sul; Atta bisphaerica presented restricted occurrence, only at the state of São Paulo. Atta cephalotes and A. opaciceps, were collected in the expected regions, North and Northeast, respectively. The Southeast region was characterized by the occurrence of $A$. capiguara and $A$. laevigata, in this order, with $A$. laevigata being the most frequent species in Minas Gerais and A. capiguara in Paraná. The occurrence of A. laevigata was recorded for the first time in Amapá and Rio Grande do Sul. 
Table 2. Geographical location of the collect sites of material received in the laboratory of Social Insects-Prague for identification.

\begin{tabular}{|c|c|c|c|}
\hline State & County & Longitude & Latitude \\
\hline Alagoas & Maceió & $-09^{\circ} 66^{\prime} 58^{\prime \prime}$ & $-35^{\circ} 73^{\prime} 52^{\prime \prime}$ \\
\hline Amapá & Porto Grande & $-00^{\circ} 71^{\prime} 33^{\prime \prime}$ & $-51^{\circ} 41^{\prime} 33^{\prime \prime}$ \\
\hline Bahia & Barra do Cacau & 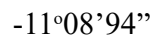 & $-43^{\circ} 14^{\prime} 16^{\prime \prime}$ \\
\hline Bahia & Barra do Rocha & $-14^{\circ} 21^{\prime} 05^{\prime \prime}$ & $-39^{\circ} 60^{\prime} 19^{\prime \prime}$ \\
\hline Bahia & Mangue Seco & $-11^{\circ} 13^{\prime} 42^{\prime \prime}$ & $-36^{\circ} 29^{\prime} 14^{\prime \prime}$ \\
\hline Bahia & Maraú & $-14^{\circ} 10^{\prime} 30^{\prime \prime}$ & $-39^{\circ} 01^{\prime} 47^{\prime \prime}$ \\
\hline Bahia & Salvador & $-12^{\circ} 97^{\prime} 11^{\prime \prime}$ & $-38^{\circ} 51^{\prime} 08^{\prime \prime}$ \\
\hline Distrito Federal & Brasília & $-15^{\circ} 77^{\prime} 97^{\prime \prime}$ & $-47^{\circ} 93^{\prime} 00^{\prime \prime}$ \\
\hline Goiás & Caldas Novas & $-17^{\circ} 74^{\prime} 16^{\prime \prime}$ & $-48^{\circ} 63^{\prime} 05^{\prime \prime}$ \\
\hline Maranhão & São Luís & $-02^{\circ} 52^{\prime} 97^{\prime \prime}$ & $-44^{\circ} 30^{\prime} 27^{\prime \prime}$ \\
\hline Minas Gerais & Araxá & $-19^{\circ} 59^{\prime} 33^{\prime \prime}$ & $-46^{\circ} 04^{\prime} 05^{\prime \prime}$ \\
\hline Minas Gerais & Itaguara & $-20^{\circ} 30^{\prime} 22^{\prime \prime}$ & $-44^{\circ} 48^{\prime} 75^{\prime \prime}$ \\
\hline Minas Gerais & Jaíba & $-15^{\circ} 33^{\prime} 83^{\prime \prime}$ & $-43^{\circ} 67^{\prime} 44^{\prime \prime}$ \\
\hline Minas Gerais & Piumhi & $-20^{\circ} 46^{\prime} 52^{\prime \prime}$ & $-45^{\circ} 95^{\prime} 80^{\prime \prime}$ \\
\hline Minas Gerais & $\begin{array}{c}\text { São Gonçalo } \\
\text { do Abaeté }\end{array}$ & $-18^{\circ} 33^{\prime} 83^{\prime \prime}$ & $-45^{\circ} 83^{\prime} 33^{\prime \prime}$ \\
\hline Mato Grosso & $\begin{array}{c}\text { Campo Novo } \\
\text { dos Parecis }\end{array}$ & $-13^{\circ} 67^{\prime} 52^{\prime \prime}$ & $-57^{\circ} 89^{\prime} 19^{\prime \prime}$ \\
\hline Mato Grosso & Sapezal & $-12^{\circ} 98^{\prime} 94^{\prime \prime}$ & $-58^{\circ} 76^{\prime} 41^{\prime \prime}$ \\
\hline Pernambuco & Petrolina & $-09^{\circ} 39^{\prime} 86^{\prime \prime}$ & $-40^{\circ} 50^{\prime} 08^{\prime \prime}$ \\
\hline Paraná & Arapoti & $-24^{\circ} 15^{\prime} 07^{\prime \prime}$ & $-49^{\circ} 82^{\prime} 66^{\prime \prime}$ \\
\hline Paraná & Bandeirantes & $-23^{\circ} 11^{\prime} 00^{\prime \prime}$ & $-50^{\circ} 36^{\prime} 75^{\prime \prime}$ \\
\hline Paraná & Cornélio Procópio & $-23^{\circ} 18^{\prime} 11^{\prime \prime}$ & $-50^{\circ} 64^{\prime} 66^{\prime \prime}$ \\
\hline Paraná & Curitiba & $-25^{\circ} 42^{\prime} 77^{\prime \prime}$ & $-49^{\circ} 27^{\prime} 30^{\prime \prime}$ \\
\hline Paraná & Doutor Camargo & $-23^{\circ} 55^{\prime} 58^{\prime \prime}$ & $-52^{\circ} 21^{\prime} 80^{\prime \prime}$ \\
\hline Paraná & Guarapuava & $-25^{\circ} 39^{\prime} 52^{\prime \prime}$ & $-51^{\circ} 45^{\prime} 80^{\prime \prime}$ \\
\hline Paraná & Matelândia & $-25^{\circ} 24^{\prime} 08^{\prime \prime}$ & $-53^{\circ} 99^{\prime} 63^{\prime \prime}$ \\
\hline Paraná & Palotina & $-24^{\circ} 28^{\prime} 38^{\prime \prime}$ & $-53^{\circ} 84^{\prime} 00^{\prime \prime}$ \\
\hline Paraná & Paranaguá & $-25^{\circ} 31^{\prime} 00^{\prime \prime}$ & $-48^{\circ} 31^{\prime} 00^{\prime \prime}$ \\
\hline Paraná & Paula Freitas & $-26^{\circ} 20^{\prime} 83^{\prime \prime}$ & $-50^{\circ} 93^{\prime} 80^{\prime \prime}$ \\
\hline Paraná & Porto Vitória & $-26^{\circ} 16^{\prime} 11^{\prime \prime}$ & $-51^{\circ} 23^{\prime} 16^{\prime \prime}$ \\
\hline Paraná & Telêmaco Borba & $-24^{\circ} 32^{\prime} 38^{\prime \prime}$ & $-50^{\circ} 61^{\prime} 55^{\prime \prime}$ \\
\hline Rio de Janeiro & Angra dos Reis & $-23^{\circ} 06^{\prime} 61^{\prime \prime}$ & $-44^{\circ} 31^{\prime} 80^{\prime \prime}$ \\
\hline Rio de Janeiro & Parati & $-23^{\circ} 21^{\prime} 77^{\prime \prime}$ & $-44^{\circ} 71^{\prime} 30^{\prime \prime}$ \\
\hline Rio Grande do Sul & Passo Fundo & $-28^{\circ} 26^{\prime} 27^{\prime \prime}$ & $-52^{\circ} 40^{\prime} 66^{\prime \prime}$ \\
\hline Rio Grande do Sul & Arroio dos Ratos & $-30^{\circ} 07^{\prime} 72^{\prime \prime}$ & $-51^{\circ} 72^{\prime} 91^{\prime \prime}$ \\
\hline Rio Grande do Sul & Butiá & $-30^{\circ} 11^{\prime} 97^{\prime \prime}$ & $-51^{\circ} 96^{\prime} 22^{\prime \prime}$ \\
\hline Rio Grande do Sul & Charqueadas & $-30^{\circ} 73^{\prime} 27^{\prime \prime}$ & $-51^{\circ} 64^{\prime} 53^{\prime \prime}$ \\
\hline Rio Grande do Sul & Gravataí & $-29^{\circ} 94^{\prime} 44^{\prime \prime}$ & $-50^{\circ} 99^{\prime} 19^{\prime \prime}$ \\
\hline Rio Grande do Sul & Porto Alegre & $-30^{\circ} 03^{\prime} 30^{\prime \prime}$ & $-51^{\circ} 23^{\prime} 00^{\prime \prime}$ \\
\hline Rio Grande do Sul & Tapes & $-30^{\circ} 67^{\prime} 33^{\prime \prime}$ & $-51^{\circ} 39^{\prime} 58^{\prime \prime}$ \\
\hline Santa Catarina & Abelardo Luz & $-26^{\circ} 56^{\prime} 47^{\prime \prime}$ & $-52^{\circ} 32^{\prime} 83^{\prime \prime}$ \\
\hline Santa Catarina & Caibí & $-27^{\circ} 07^{\prime} 16^{\prime \prime}$ & $-53^{\circ} 24^{\prime} 77^{\prime \prime}$ \\
\hline Santa Catarina & Cordilheira Alta & $-26^{\circ} 95^{\prime} 88^{\prime \prime}$ & $-52^{\circ} 76^{\prime} 11^{\prime \prime}$ \\
\hline
\end{tabular}

\begin{tabular}{|c|c|c|c|}
\hline State & County & Longitude & Latitude \\
\hline Santa Catarina & Coronel Freitas & $-26^{\circ} 90^{\prime} 86^{\prime \prime}$ & $-52^{\circ} 70^{\prime} 30^{\prime \prime}$ \\
\hline Santa Catarina & Cunha Porã & $-26^{\circ} 89^{\prime} 36^{\prime \prime}$ & $-53^{\circ} 16^{\prime} 80^{\prime \prime}$ \\
\hline Santa Catarina & Descanso & $-26^{\circ} 82^{\prime} 61^{\prime \prime}$ & $-53^{\circ} 50^{\prime} 16^{\prime \prime}$ \\
\hline Santa Catarina & $\begin{array}{l}\text { Dionisio } \\
\text { Cerqueira }\end{array}$ & $-26^{\circ} 25^{\prime} 05^{\prime \prime}$ & $-53^{\circ} 63^{\prime} 97^{\prime \prime}$ \\
\hline Santa Catarina & Galvão & $-26^{\circ} 45^{\prime} 05^{\prime \prime}$ & $-52^{\circ} 68^{\prime} 58^{\prime \prime}$ \\
\hline Santa Catarina & Irani & $-27^{\circ} 02^{\prime} 47^{\prime \prime}$ & $-51^{\circ} 90^{\prime} 16^{\prime \prime}$ \\
\hline Santa Catarina & Ita & $-27^{\circ} 29^{\prime} 05^{\prime \prime}$ & $-52^{\circ} 32^{\prime} 30^{\prime \prime}$ \\
\hline Santa Catarina & Itapiranga & $-27^{\circ} 16^{\prime} 94^{\prime \prime}$ & $-53^{\circ} 73^{\prime} 22^{\prime \prime}$ \\
\hline Santa Catarina & Jupiá & $-26^{\circ} 39^{\prime} 83^{\prime \prime}$ & $-52^{\circ} 72^{\prime} 77^{\prime \prime}$ \\
\hline Santa Catarina & Maravilha & $-26^{\circ} 76^{\prime} 08^{\prime \prime}$ & $-53^{\circ} 17^{\prime} 25^{\prime \prime}$ \\
\hline Santa Catarina & Nova Erexim & $-26^{\circ} 90^{\prime} 25^{\prime \prime}$ & $-52^{\circ} 90^{\prime} 58^{\prime \prime}$ \\
\hline Santa Catarina & Palmitos & $-27^{\circ} 06^{\prime} 75^{\prime}$ & $-53^{\circ} 16^{\prime} 11^{\prime \prime}$ \\
\hline Santa Catarina & Pinhalzinho & $-26^{\circ} 84^{\prime} 80^{\prime \prime}$ & $-52^{\circ} 99^{\prime} 19^{\prime \prime}$ \\
\hline Santa Catarina & Piratuba & $-27^{\circ} 41^{\prime} 97^{\prime \prime}$ & $-51^{\circ} 77^{\prime} 19^{\prime \prime}$ \\
\hline Santa Catarina & Quilombo & $-26^{\circ} 72^{\prime} 61^{\prime \prime}$ & $-52^{\circ} 72^{\prime} 05^{\prime \prime}$ \\
\hline Santa Catarina & São Carlos & $-27^{\circ} 07^{\prime} 75^{\prime \prime}$ & $-53^{\circ} 00^{\prime} 38^{\prime \prime}$ \\
\hline Santa Catarina & São José Cedro & $-26^{\circ} 45^{\prime} 05^{\prime \prime}$ & $-53^{\circ} 49^{\prime} 41^{\prime \prime}$ \\
\hline Santa Catarina & $\begin{array}{l}\text { São Lourenço } \\
\text { do Oeste }\end{array}$ & $-26^{\circ} 35^{\prime} 91^{\prime \prime}$ & $-52^{\circ} 85^{\prime} 11^{\prime \prime}$ \\
\hline Santa Catarina & $\begin{array}{l}\text { São Miguel } \\
\text { do Oeste }\end{array}$ & $-26^{\circ} 72^{\prime} 52^{\prime \prime}$ & $-53^{\circ} 51^{\prime} 80^{\prime \prime}$ \\
\hline Santa Catarina & Saudades & $-26^{\circ} 92^{\prime} 41^{\prime \prime}$ & $-53^{\circ} 00^{\prime} 30^{\prime \prime}$ \\
\hline Santa Catarina & Vargeão & $-26^{\circ} 86^{\prime} 36^{\prime \prime}$ & $-52^{\circ} 15^{\prime} 05^{\prime \prime}$ \\
\hline Santa Catarina & Xaxim & $-26^{\circ} 96^{\prime} 16^{\prime \prime}$ & $-52^{\circ} 53^{\prime} 47^{\prime \prime}$ \\
\hline São Paulo & Agudos & $-22^{\circ} 46^{\prime} 91^{\prime \prime}$ & $-48^{\circ} 98^{\prime} 75^{\prime \prime}$ \\
\hline São Paulo & Altinópolis & $-21^{\circ} 02^{\prime} 55^{\prime}$ & $-47^{\circ} 37^{\prime} 38^{\prime \prime}$ \\
\hline São Paulo & Assis & $-22^{\circ} 66^{\prime} 16^{\prime \prime}$ & $-50^{\circ} 41^{\prime} 22^{\prime \prime}$ \\
\hline São Paulo & Cananéia & $-25^{\circ} 01^{\prime} 47^{\prime \prime}$ & $-47^{\circ} 92^{\prime} 66^{\prime \prime}$ \\
\hline São Paulo & Eldorado & $-24^{\circ} 52^{\prime} 00^{\prime \prime}$ & $-48^{\circ} 10^{\prime} 80^{\prime \prime}$ \\
\hline São Paulo & Franca & $-20^{\circ} 53^{\prime} 86^{\prime \prime}$ & $-47^{\circ} 43^{\prime} 03^{\prime \prime}$ \\
\hline São Paulo & Igarapava & $-20^{\circ} 03^{\prime} 83^{\prime \prime}$ & $-47^{\circ} 74^{\prime} 69^{\prime \prime}$ \\
\hline São Paulo & Itapetininga & $-23^{\circ} 59^{\prime} 16^{\prime \prime}$ & $-48^{\circ} 05^{\prime} 30^{\prime \prime}$ \\
\hline São Paulo & Itatinga & $-23^{\circ} 10^{\prime} 16^{\prime \prime}$ & $-48^{\circ} 61^{\prime} 58^{\prime \prime}$ \\
\hline São Paulo & Jaboticabal & $-21^{\circ} 25^{\prime} 47^{\prime \prime}$ & $-48^{\circ} 32^{\prime} 22^{\prime \prime}$ \\
\hline São Paulo & Juquiá & $-24^{\circ} 32^{\prime} 08^{\prime \prime}$ & $-47^{\circ} 63^{\prime} 47^{\prime \prime}$ \\
\hline São Paulo & Lençóis Paulista & $-22^{\circ} 59^{\prime} 86^{\prime \prime}$ & $-48^{\circ} 80^{\prime} 02^{\prime \prime}$ \\
\hline São Paulo & Mongaguá & $-24^{\circ} 09^{\prime} 16^{\prime \prime}$ & $-46^{\circ} 61^{\prime} 77^{\prime \prime}$ \\
\hline São Paulo & Nazaré Paulista & $-23^{\circ} 18^{\prime} 11^{\prime \prime}$ & $-46^{\circ} 39^{\prime} 05^{\prime \prime}$ \\
\hline São Paulo & Peruíbe & $-24^{\circ} 32^{\prime} 00^{\prime \prime}$ & $-46^{\circ} 99^{\prime} 83^{\prime \prime}$ \\
\hline São Paulo & Piracicaba & $-22^{\circ} 72^{\prime} 52^{\prime \prime}$ & $-47^{\circ} 64^{\prime} 91^{\prime \prime}$ \\
\hline São Paulo & $\begin{array}{l}\text { Santa Rosa } \\
\text { de Viterbo }\end{array}$ & $-21^{\circ} 47^{\prime} 27^{\prime \prime}$ & $-47^{\circ} 36^{\prime} 30^{\prime \prime}$ \\
\hline São Paulo & Ubatuba & $-23^{\circ} 43^{\prime} 38^{\prime \prime}$ & $-45^{\circ} 07^{\prime} 11^{\prime \prime}$ \\
\hline
\end{tabular}


Table 3. Percentage of municipalities $(n=300)$ with the occurrence of species and subspecies of Atta North, Northeast, Midwest, Southeast and South regions of Brazil.

\begin{tabular}{lcccccc}
\hline \multicolumn{1}{c}{ Species } & North & Northeast & Midwest & Southeast & South & Brazil \\
\hline A. laevigata & 6.0 & 0.3 & 20.3 & 5.0 & 1.0 & 32.6 \\
A. capiguara & $-*$ & - & 8.7 & 7.0 & 4.3 & 20.0 \\
A. sexdens rubropilosa & - & 0.3 & 2.7 & 2.0 & 5.0 & 10.0 \\
A. sexdens piriventris & - & - & - & - & 9.7 & 9.7 \\
A. sexdens sexdens & 2.7 & - & - & - & - & 2.7 \\
A. cephalotes & 1.3 & 0.3 & - & - & - & 1.6 \\
A. bisphaerica & - & - & - & 0.3 & - & 0.3 \\
A. opaciceps & - & 0.3 & - & - & - & 0.3 \\
A. vollenweideri & - & - & - & - & 0.3 & 0.3 \\
\hline
\end{tabular}

*No collection

\section{Discussion}

\section{Atta laevigata}

Atta laevigata was the only species found in all regions of Brazil (Fig 1). The results are consistent with previous studies that already indicated the occurrence of this species in the five Brazilian geographic regions (Castro et al., 1961; Della Lucia et al., 1993). Gonçalves (1967) reported the presence of $A$. laevigata in Manaus, Óbidos and São Gabriel (Northern region), where this species was found on roadsides and in crops, including under the shade of trees in covered areas. The Cerrado region is an adequate habitat for A. laevigata, as observed by high-density nests recorded in Cerrado areas also highlight the suitability of this vegetation type (Costa \& Vieira-Neto, 2016).

Although in the present study the occurrence of $A$. laevigata was not recorded in the Northeast of Brazil, this species was found by Gonçalves (1951) in Ceará, Pernambuco and Bahia in dicotyledons, wild grasses, eucalyptus and cassava. Subsequently, Brito et al. (2012), recorded the occurrence of A. laevigata in four municipalities in southwestern Bahia, in areas of pasture, eucalyptus and forest. These municipalities are inserted in environments of Caatinga, Cerrado and deciduous seasonal forest. The Southeastern region of Brazil showed the third highest frequency of A. laevigata According to Antunes (1996), part of the southeastern region is occupied by Cerrado and a large area of Minas Gerais is covered with this type of vegetation. For the two states of the Southeastern Region (Minas Gerais and São Paulo), the occurrence of $A$. laevigata had already been recorded (Della Lucia et al., 1993).

The Cerrado biome (Brazilian Savanna) covers 2 million $\mathrm{km}^{2}$ representing $23 \%$ of the area of the country. It is an ancient biome with rich biodiversity, estimated at 160,000 species of plants, fungi and animals (MMA, 2020). The predominant vegetation of the woods is composed of small trees with twisted trunks with irregular ramifications; with shrubs and sub-shrubs that may have xylopodios, underground organs, which allow regrowth after burning or cutting, this being denominate cerrado senso stricto, one of the various components of the physiognomy mosaic of the Cerrado biome. In the Southern region, A. laevigata was rarely frequent (Table 3 ). However, the record of its occurrence in Rio Grande do Sul (Southern Region, municipality of Tapes).

In general, A. laevigata partially present in many municipalities (Fig 1), mainly due to the opening of highways and expansion of livestock, which serve as means for the dispersion of the species (Vieira-Neto et al., 2016), as well as the opening of agricultural frontiers in Cerrado areas, which involve the deforestation of natural forests and the plantation of monocultures and pastures. The first reference of this species in Espírito Santo was confirmed in the work of Delabie (1998), whose author, after morphological studies of several samples of A. laevigata from different regions of Brazil, concluded that Atta silvai Gonçalves, registered in that state, is a junior synonym of A. laevigata. These species occurred in a greater percentage on sampled municipalities in relation to $A$. sexdens. This result is probably related to the collection sites that covered areas close to the highways and that favor the nesting of A. laevigata (Forti et al., 2011). A. laevigata is aggressive in the selection of nesting areas, since nests are built in both sunny and shady (Mariconi, 1970; Pereira da Silva, 1975; Moreira et al., 2004) and the forager workers select mono and dicotyledonous plants as growth substrate of the symbiont fungus (Della Lucia et al., 1993; Forti et al., 2011).

\section{Atta capiguara}

The species A. capiguara, commonly known as brown leaf-cutting ant, exploits monocotyledon plants, basically grasses, and is economically important in sugarcane fields and pastures (Amante, 1967; Mariconi, 1970; Forti, 1985). Atta capiguara was found in the Southeast, Mid-west and South regions in $7.0 \%, 8.7 \%$ and $4.3 \%$ of sampled municipalities more restricted in its Brazilian distribution range. Its occurrence had already been reported for the states of São Paulo, Mato Grosso and Minas Gerais (Della Lucia et al., 1993) and also for Paraná, Mato Grosso do Sul and Goiás (Forti \& Boaretto, 1997).

The highest concentration of $A$. capiguara was observed in the State of Paraná (Southern Region) (Fig 1). The common 


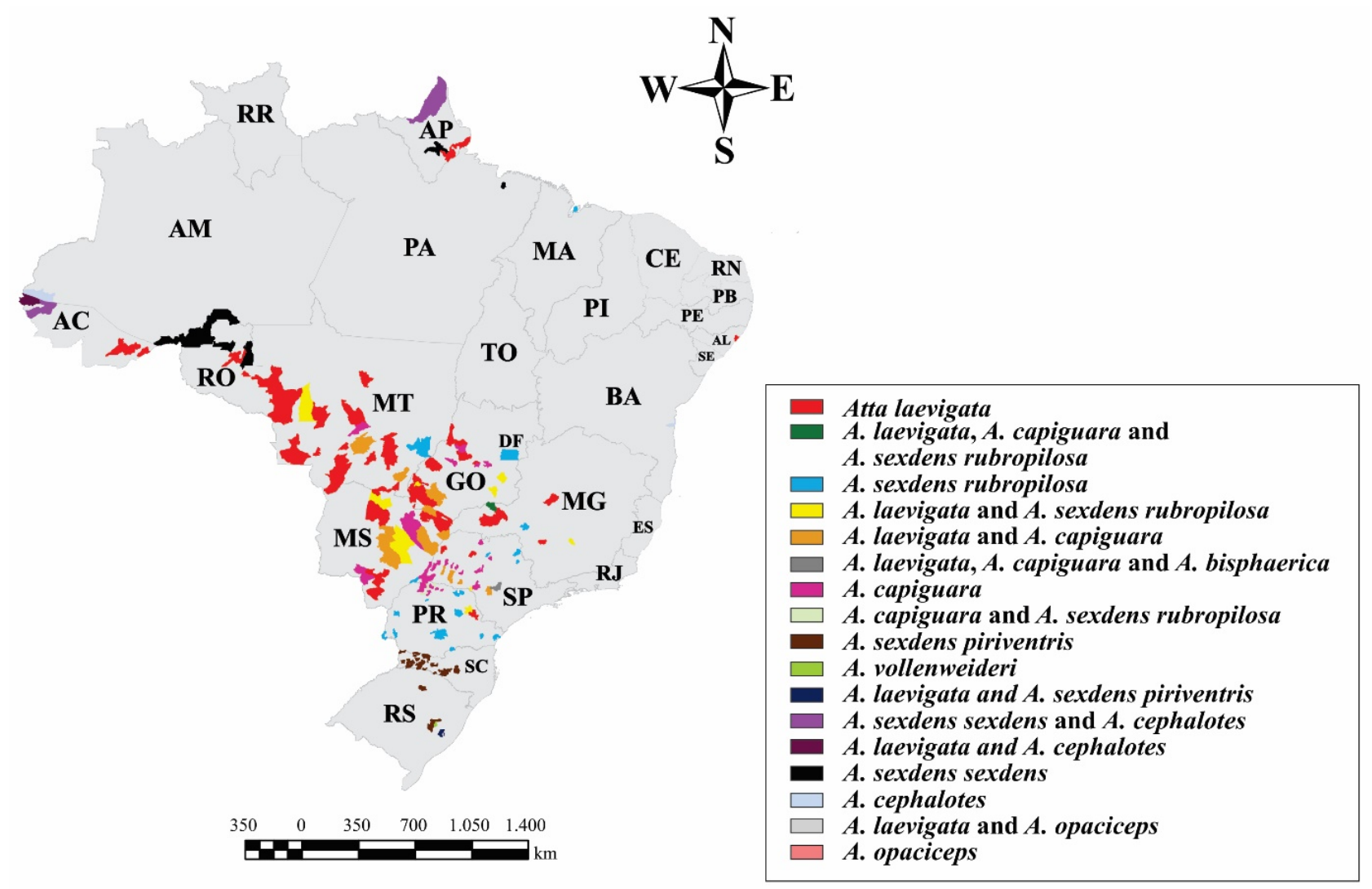

Fig 1. Atta species recorded in the municipalities of the North, Northeast, Midwest, Southeast and Southern regions of Brazil.

characteristics of municipalities where A. capiguara was found are sandy soil and plant nutrient deficiency, as well as the native vegetation classified as Tropical Forest (BRAZIL, 1998).

Smaller size forests resembling secondary forests occur in these soils were naturally fertility is poor and used as pasture lands (Wons, 1985). The characteristics of the Cerrado are typical in most parts of this ecoregion, but gradual changes are observed due to climatic influences of neighboring regions (Adámoli et al., 1986). Two parameters should be highlighted since they define the characteristics of the seasonal regime of this region: the average annual rainfall of 1,200 to 1,800 $\mathrm{mm}$ and the duration of the dry season that ranges from 5 to 6 months. The average annual temperature is $22^{\circ} \mathrm{C}$ in the southern part of this ecoregion and $27^{\circ} \mathrm{C}$ in the northern part. Its vegetation consists of isolated or groups of winding small trees on a continuous grass rug (BRAZIL, 1998).

The importance of $A$. capiguara has been known since the 1940s, with observations of nests in some localities with predominance of grasses in municipalities of the State of São Paulo (Gonçalves, 1945). Surveys conducted in other municipalities increased the occurrence of this species to 17 municipalities (Mariconi et al., 1961). Mariconi (1966b) also recorded the occurrence of $A$. capiguara in 104 municipalities in the western region of the State of São Paulo. Amante (1967) cited the occurrence of A. capiguara in Mato Grosso do Sul and Minas Gerais. Although not mentioning the municipalities, Thomas (1990) reported that A. capiguara had become a serious problem in two municipalities of the northwestern region of Paraná after 1975 and, by 1990, this species had damaged pastures in more than 32 municipalities of that state.

Many factors could have contributed to the population explosion of this species, such as disturbances caused by humans when they replaced the natural vegetation with grass monocultures (Forti \& Boaretto, 1997). According to Thomas (1990), the reduction of areas with natural vegetation and the substitution of crops such as coffee, peanuts and other crops for pastures facilitated the rapid growth of $A$. capiguara infestation in Paraná. The increased availability of monocotyledonous plants, especially exotic grasses, allows grass-cutting ants to expand their distribution and increase population density (Cherrett, 1981).

\section{Atta sexdens}

The subspecies A. sexdens rubropilosa was registered in all Brazilian regions (Fig 1), except in the North, while A. sexdens piriventris and $A$. sexdens sexdens were of more restricted occurrence, only in the South and North regions, respectively. This result reflects the adaptability de $A$. sexdens rubropilosa to the different environmental conditions of the country (Farji-Brener \& Ghermandi, 2008). A large number of studies on this leaf-cutting ant subspecies are available and its occurrence has been reported in several states, including Minas Gerais, Espírito Santo, Goiás, Mato Grosso, São Paulo, Paraná, Rio de Janeiro and Distrito Federal (Gonçalves, 1945; Della Lucia et al., 1993). Atta sexdens piriventris was observed in the South region. The occurrence of this subspecies was 
predominant in Santa Catarina. In the state of Rio Grande do Sul, A. sexdens piriventris occurred in most of the sampled municipalities, corroborating the studies by Loeck and Grützmacher (2001) and Grürzmacher et al. (2002).

The main environmental characteristics that distinguish this region from other areas are lower average temperatures $\left(16^{\circ} \mathrm{C}\right.$ and $\left.20^{\circ} \mathrm{C}\right)$ and uniform rainfall throughout the year, which are typical of subtropical climates (Antunes, 1996). Associated with this climate, the vegetation ranges from Atlantic Rainforest, Tropical Forest and Araucaria Forest to fields and coastal vegetation (Carraro, 1994). Supporting the hypothesis that this species tends to occupy climate environments such as those described above, in the State of Paraná this species was only found in the municipality of Paula Freitas, located at the southern end of the state (Fig 1). The north of Paraná, where a significant number of the municipalities visited are located, is found in an intertropical transition zone characterized by high average temperatures and a rainy period concentrated in the summer months (Antunes, 1996).

This distribution in Paraná resembles that observed in the Southeast and, within this region, in the State of São Paulo (Fig 1). This fact is possibly associated with the similar environmental conditions in these border states, since the municipalities sampled in Paraná are concentrated in the northern and northwestern regions of the state as mentioned above.

The subspecie Atta sexdens sexdens was exclusively recorded in the northern region (Fig 1). However, the occurrence of this subspecies has already been reported by Della Lucia et al. (1993) for the Mid-west, Northeast and Southeast regions. According to Delabie (1989), this leaf-cutting ant occurs in the State of Bahia (Northeast Region of Brazil) in more open areas and is more generalist in its foraging, attacking several dicotyledonous plants of economic importance (cacao, cassava and citrus) and also forage grasses, being more abundant in pastures. The occurrence of this ant in the state of Alagoas (Northeast Region of Brazil) was recorded by Souza et al. (2009).

\section{Atta cephalotes}

Atta cephalotes was found in the North region, in 1.3\% of sampled municipalities. The State of Amazonas (North Region) was represented by only one locality (Guajará) where A. cephalotes was collected. The occurrence of A. cephalotes was recorded during the travels in Oiapoque (Amapá) and in Cruzeiro do Sul and Mâncio Lima (Acre) (Fig 1), as well as in material sent for identification from Maraú in Bahia (North region) (Fig 1), sites of occurrence of this species already cited in the literature. This result was expected, because $A$. cephalotes is a species easily found in the forests of Amazonia and is the most demanding leaf-cutting ant in terms of soil moisture (Gonçalves, 1960). In the Northeast region, this ant had already been reported to the States of Maranhão, Pernambuco, Bahia (Mariconi, 1970; Kempf, 1972) and Alagoas (Corrêa et al., 2005).

\section{Atta bisphaerica}

In this work, A. bisphaerica occurred only in the Southeast region (Fig 1), in the municipality of Botucatu, São Paulo, which was not expected, considering that the possibilities of expansion of this ant, as well as in A. capiguara, are associated with the substitution of natural vegetation and agricultural crops by pasture and sugarcane, since this species preferentially cuts monocotyledonous plants, it was expected an increase of its occurrence. For example, in the state of São Paulo, A. capiguara (Amante, 1972) and A. bisphaerica (Precetti et al., 1988) are of great economic importance in sugarcane and pasture, but only A. capiguara has high occurrence. Nevertheless, $A$. bisphaerica has been more associated to sugarcane and A. capiguara to pasture areas. In sugarcane crops, the chemical control of leaf-cutting ants is quite intense, with the systematic use of thermonebulization, contributing to a significant reduction of nest density, which usually does not occur in pastures, which could explain the lower expansion of $A$. bisphaerica in relation to A. capiguara.

The occurrence of $A$. bisphaerica had already been reported in other states of Southeastern Brazil (Minas Gerais and Rio de Janeiro), as well as in the Mid-western region (Mato Grosso) (Della Lucia et al., 1993).

\section{Atta opaciceps}

The occurrence of $A$. opaciceps was observed in the Northeast region, state of Alagoas (municipality of Maceió) (Fig 1), a finding also reported by Souza et al. (2009), but was distributed in the Caatinga region. The occurrence of this species was also reported for the states of Sergipe (Delabie et al., 1997) and Bahia (Delabie et al., 1997; Brito et al., 2012) for the North and Southweste regions of Brazil. The hypothesis raised by Fowler et al. (1990) that this leaf-cutting ant could be in extinction has not been confirmed.

\section{Atta vollenweideri}

Atta vollenweideri, which usually cuts the leaves of grasses and dicotyledons, was recorded only in the South region, in the municipality of Arroio dos Ratos, state of Rio Grande do Sul (Fig 1). This species is of very restricted occurrence, being recorded only for two Brazilian states, Rio Grande do Sul (Gonçalves, 1960; 1971; Jonkman, 1978; Della Lucia et al., 1993) and Mato Grosso (Della Lucia et al., 1993).

In general, the results expand the knowledge about leafcutting ants of the Atta genus in Brazilian regions, since the work encompassed many municipalities until then not sampled. The first record of the occurrence of A. laevigata in Amapá and Rio Grande do Sul, as well as the presence of A. opaciceps in municipalities of Alagoas, a quite what positive aspect once it were already raice possibility treat of being a species extinction. Atta laevigata, A. sexdens (considering its subspecies) and A. capiguara are species of wide occurrence in the Brazilian territory. Atta cephalotes, A. bisphaerica, A. opaciceps and A. vollenweideri are species of very restricted occurrence. 
We consider that the data presented in this work can be integrated into the databases on leaf-cutting ants, the example of created and used by Delabie et al. (2011), to expand the studies of regional clusters with identification of the main associated vectors and that allow the prediction of the occurrence of Atta species.

\section{Acknowledgements}

LCF was the recipient of a fellowship from Conselho Nacional de Desenvolvimento Cientifico e Tecnológico (Grant 301718/2013-0).

Table 1. Geographical location of the collect sites visited by routes (I to V), during the trips.

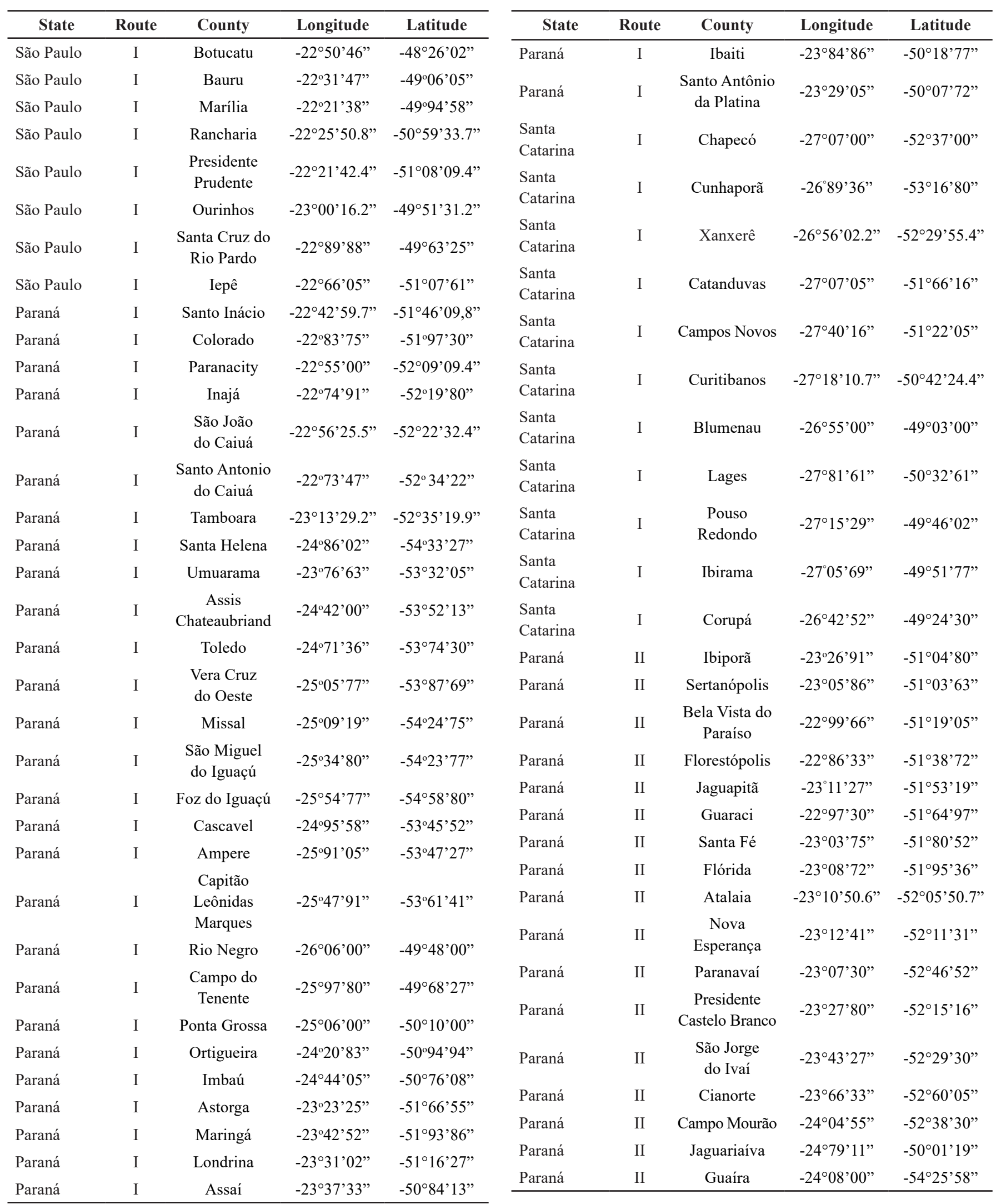


Table 1. Geographical location of the collect sites visited by routes (I to V), during the trips. (Continuation)

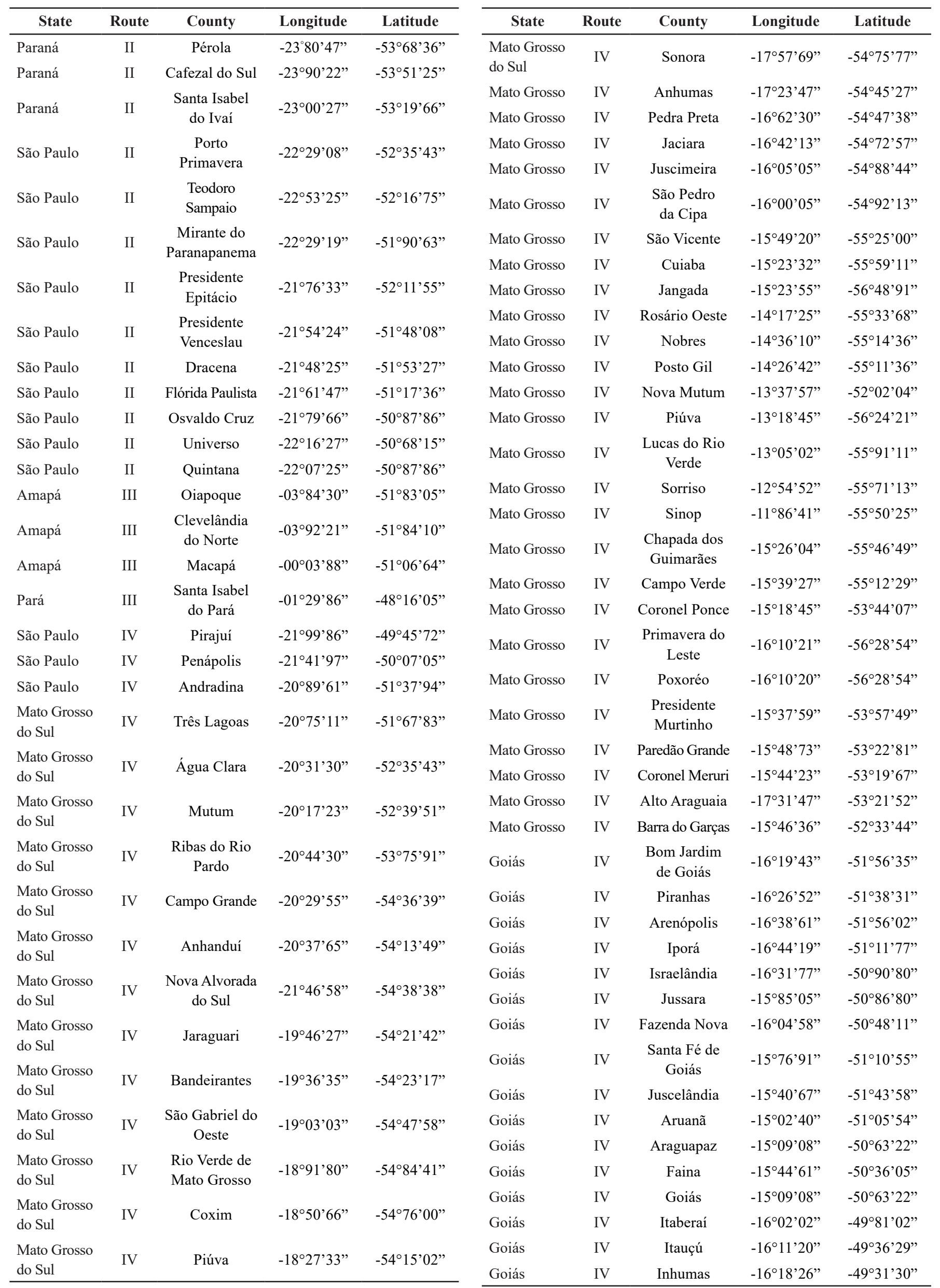


Table 1. Geographical location of the collect sites visited by routes (I to V), during the trips. (Continuation)

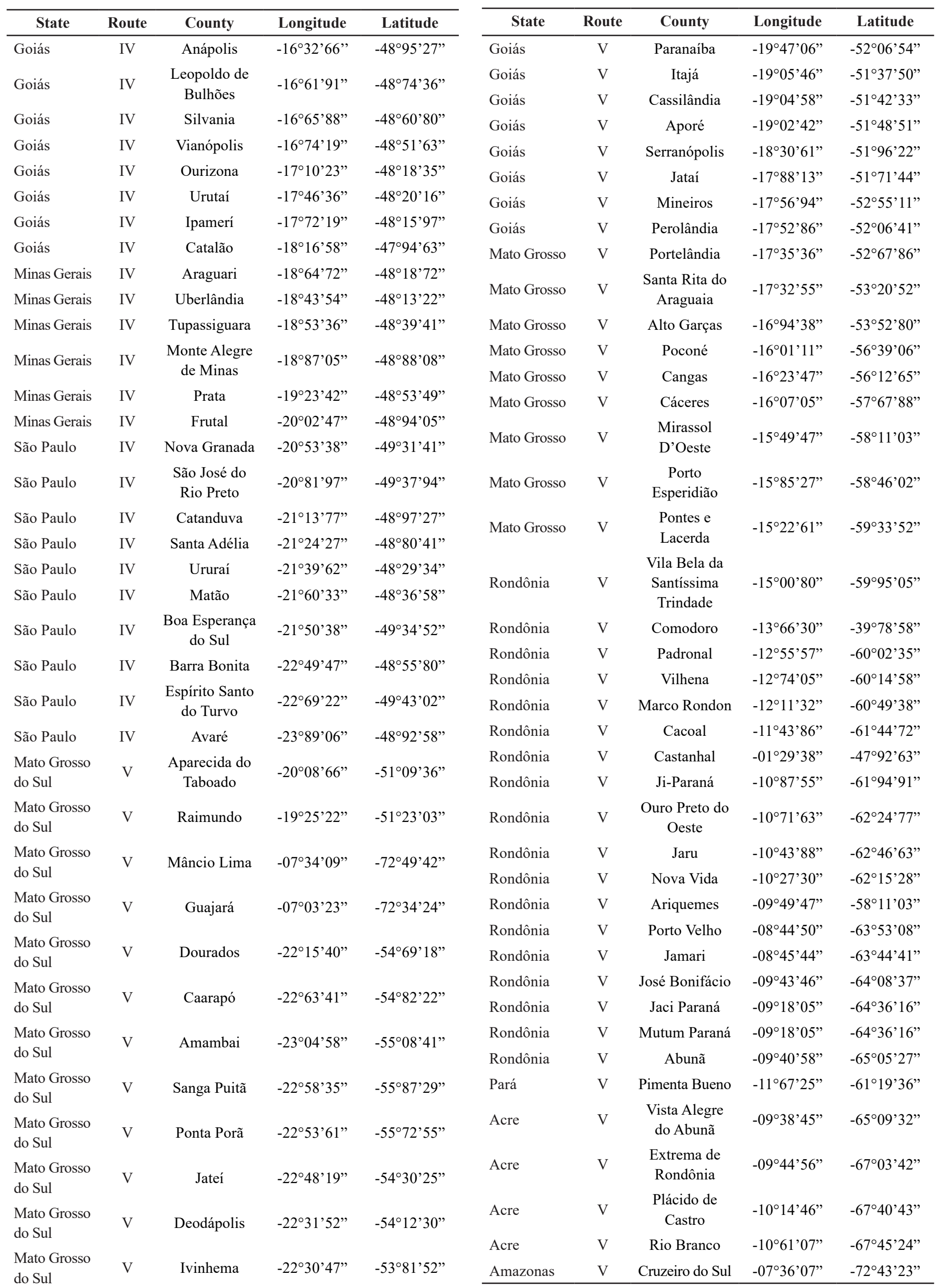




\section{References}

Adámoli, J., Macedo, J., Azevedo, L.G. de \& Netto, J.M. (1986). Caracterização da região dos Cerrados. In: GOEDERT W (Eds). Solos dos Cerrados (pp.33-74). São Paulo: Nobel.

Amante, E. (1967). A formiga saúva Atta capiguara, praga das pastagens. O Biológico, 33: 113-120.

Antunes, C. (1996). Geografia e participação. São Paulo: Scipione, $150 \mathrm{p}$.

Bacci, M., Solomon, S.E., Mueller, U.G., Martins, V.G, Carvalho, A.O.R, Vieira, L.G.E. \& Silva-Pinhati, A.C.O. (2009). Phylogeny of leafcutter ants in the genus Atta Fabricius (Formicidae: Attini) based on mitochondrial and nuclear DNA sequences. Molecular Phylogenetics and Evolution, 51: 427-437. doi: 10.1016/j.ympev.2008.11.005

Bolton, B., Alpert, G., Ward, P.S. \& Naskrecki, P. (2006). Bolton's catalogue of ants of the world: 1758-2005. Cambridge: Harvard University Press, CD interativo.

Borgmeier, T.O.F.M. (1959). Revision der Gattung Atta Fabricius (Hymenoptera, Formicidae). Studia Entomologica, 2: 321 390. doi: 10.5281/zenodo.26900

Brandão, C.R.F., Maye-Nunes, A. \& Sanhudo, C.E.D. (2011). Taxonomia e filogenia das formigas-cortadeiras. In: T.M.C. Della-Lucia (Eds). Formigas cortadeiras: da bioecologia ao manejo (pp.28-48). Viçosa: UFV.

Brasil. (1998). Fundação Instituto Brasileiro de Geografia e Estatística. Anuário Estatístico do Brasil (pp.101-135). Rio Janeiro.

Brito, A.F., Melo, T.L., Castellani, M.A., Forti, L.C., Andrade, A.P.P., Ribeiro, A.E.L., Lemos, R.N.S. \& Moreira, A.A. (2012). Ocorrência de formigas cortadeiras do gênero Atta (Hymenoptera: Attini) na região sudoeste da Bahia. Magistra, 24: $210-214$.

Carraro, F. (1994). Atividades com mapas. São Paulo: FTD, 104 p.

Carvalho, S. \& Tarragô, M.F.S. (1982). Atta (Neoatta) vollenweideri Forel, 1893, no Brasil: ocorrência, aspectos externos e internos do sauveiro (Hymenoptera: Formicidae). Revista do Centro Ciências Rurais, 12: 1-20.

Castro, U. de P., Zamith, A.P.L. \& Mariconi, F.A.M. (1961). Contribuição para o conhecimento da "saúva de vidro" Atta laevigata Fred Smith, 1858. Anais da Escola Superior de Agricultura Luiz de Queiroz. 18: 313-326. doi: 10.1590/ S0071-12761961000100021

Cherrett, J.M. (1981). The interaction of wild vegetation and crops in leaf-cutting and attack. In: J.M. Thresh (Eds). Pests, pathogens, and vegetation (pp. 315-325). Boston: Pitman Advanced Publishing Program.

Corrêa, M.M., Bieber, A.G.D., Wirth, R. \& Leal, I.R. (2005). Occurrence of Atta cephalotes (L.) (Hymenoptera: Formicidae) in Alagoas, Northeastern Brazil. Neotropical Entomololy, 34: 695-698. doi: 10.1590/S1519-566X2005000400023

Costa, A.N., Vasconcelos, H.L., Vieira-Neto, E.H. \& Bruna, E.M. (2008). Do herbivores exert top-down effects in Neotropical savannas? Estimates of biomass consumption by leaf-cutter ants. Journal of Vegetation Science, 19: 849-854. doi: 10.3170/2008-8-18461

Costa, A.N. \& Vieira-Neto, E.H.M. (2016). Species turnover regulates leaf-cutter ant densities in environmental gradients across the Brazilian Cerrado. Journal of Applied Entomology, 140: 474-478. doi: 10.1111/jen. 12277

Delabie, J.C.H., Alves, H.S.R., Reuss-Strenzel, G.M., Carmo, A.D. \& Nascimento, I.D. (2011). Distribuição das formigascortadeiras Acromyrmex e Atta no Novo Mundo. In: TMC Della-Lucia (Eds). Formigas-Cortadeiras: da bioecologia ao manejo (pp.80-101). Viçosa: UFV.

Delabie, J.H.C. (1989). Novas opções para controle das formigas cortadeiras Acromyrmex subterraneus brunneus e Atta sexdens sexdens (Hymenoptera: Formicidae: Attini), na região cacaueira da Bahia, Brasil. Revista Agrotrópica, 1: 173-180.

Delabie, J.H.C., Nascimento, I.C., Fonseca, E., Sgrillo, R.B., Soares, P.A.O., Casimiro, A.B. \& Furst, M. (1997). Biogeografia das formigas cortadeiras (Hymenoptera; Formicidae; Myrmicinae; Attini) de importância econômica no leste da Bahia e nas regiões periféricas dos estados vizinhos. Agrotrópica, 9: 49-58.

Delabie, J.H.C. (1998) Atta silvai Gonçalves, sinônimo júnior de Atta laevigatta (Fred. Smith) (Hymenoptera, Formicidae, Attini). Revista Brasileira de Entomologia, 4: 339-341.

Della Lucia, T.M.C., Fowler, H.G. \& Moreira, D.D.O. (1993). Espécies de formigas cortadeiras no Brasil. In: T.M.C. Della Lucia (Eds.). As Formigas Cortadeiras (pp. 26-31). Viçosa: Folha de Viçosa.

Farji-Brener, A.G.F. \& Ruggiero, A. (1994). Leaf-cutting ants (Atta and Acromyrmex) inhabiting Argentina: patterns in species richness and geographical range sizes. Journal of Biogeography, 21: 391-399. doi: 10.2307/2845757

Farji-Brener, A.G. \& Illes, A.E. (2000). Do leaf-cutting ant nests make" bottom-up" gaps in neotropical rain forests? a critical review of the. Ecology Letters, 3: 219-227. doi: 10.1046/j.1461-0248.2000.00134.x

Farji-Brener, A.G., Elizalde, L., Fernández-Marín, H. \& Amador-Vargas, S. (2016). Social life and sanitary risks: evolutionary and current ecological conditions determine waste management in leaf-cutting ants. Proceedings of the Royal Society B: Biological Sciences, 283: 20160625. doi: 10.1098/rspb.2016.0625

Forti, L.C. \& Boaretto, M.A.C. (1997). Formigas cortadeiras: biologia, ecologia, danos e controle. Botucatu: Departamento de Defesa fitossanitária, Universidade Estadual Paulista. 61 p. 
Fowler, H.G. (1983). Distribution patterns of Paraguayan leafcutting (Atta and Acromyrmex) (Formicidae: Attini). Studies on Neotropical Fauna and Environment, 18: 121-138. doi: 10.1080/01650528309360626

Forti, L.C., Moreira, A.A., Andrade, A.P.P., Castellani, M.A. \& Caldato, N. (2011). Nidificação e Arquitetura de Ninhos de Formigas-Cortadeiras. In: TMC Della-Lucia (Eds). FormigasCortadeiras: da bioecologia ao manejo (pp.102-125). Viçosa: UFV.

Fowler, H.G., Pagani, M.I., Da Silva, O.A., Forti, L.C., Silva, V.P. \& Vasconcelos, H.L. (1989). A pest is a pest is a pest? The dilemma of neotropical leaf-cutting ants: keystone taxa of natural ecosystems. Environmental Management, 13: 671675. doi: 10.1007/BF01868306

Fowler, H.G., Bernandi, J.V.E., Delabie, J.C., Forti, L.C. \& Pereira-da-Silva, V. (1990). Major ant problems of South America. In: Vander Meer R.K., Jaffé K., Cedeño A. (Eds). Applied myrmecology: A world perspective (pp.3-14). Boulder: Westview Press.

Gonçalves, C.R. (1942). Contribuição para o conhecimento do gênero Atta Fabr., das formigas saúvas. Boletim da Sociedade Brasileira de Agronomia, 5: 333-358.

Gonçalves, C.R. (1945). Saúvas do sul e centro do Brasil. Boletim Fitossanitário, 2: 183-218.

Gonçalves, C.R. (1951). Saúvas do nordeste do Brasil (Atta spp., Formicidae). Boletim Fitossanitário, 5: 1-43.

Gonçalves, C.R. (1955). Nota suplementar sobre as saúvas do Nordeste do Brasil. Boletim Fitossanitário, 21-26.

Gonçalves, C.R. (1960). Distribuição biologia e ecologia das saúvas. Divulgação agronômica, 1: 2-10.

Gonçalves, C.R. (1961). O gênero Acromyrmex no Brasil (Hym. Formicidae). Studia Entomologica, 4: 113-180.

Gonçalves, C.R. (1967). As formigas cortadeiras da Amazônia, dos gêneros "Atta" Fabr. e "Acromyrmex" Mayr (Hym., Formicidae). In: Lent, H. (Eds.). Atas do Simpósio sobre a Biota Amazônica (Zoologia), 5: 181-202. Rio de Janeiro: Conselho Nacional de Pesquisas.

Gonçalves, C.R. (1971). As saúvas do Mato Grosso, Brasil (Hymenoptera, Formicidae). Arquivos do Museu Nacional (Rio de Janeiro), 249-253.

Grürzmacher, D.D., Loeck, A.E. \& Medeiros, A.H. (2002). Ocorrência de formigas cortadeiras na região da Depressão central do Estado do Rio Grande do Sul. Ciência Rural, 32: 185-190. doi: 10.1590/S0103-84782002000200001

Gusmão, L.G., Loeck, A.E. (1999). Distribuição geográfica de formigas cortadeiras do gênero Acromyrmex (Hymenoptera: Formicidae) na zona sul do estado do Rio Grande do Sul, Brasil. Revista Brasileira de Agrociência, 5: 64-67. doi: 10.18539/CAST.V5I1.246
Jaffé, C.K. (1993). Mundo de las Hormigas. Caracas: Equinoccio, Universidad Simon Bolivar. 188 p.

Jonkman, J.C.M. (1978). Nests of the leaf-cutting ant Atta vollenweideri as accelerators of succession in pastures. Zeitschrift für Angewandte Entomologie, 86: 25-34. doi: 10.1111/j.14390418.1978.tb01907.x

Kempf, W.W. (1972). Catálogo abreviado das formigas da Região Neotropical (Hymenoptera, Formicidae). Studia Entomologica, 15: 3-343.

Leal, I.R., Wirth, R. \& Tabarelli, M. (2014). The multiple impacts of leaf-cutting ants and their novel ecological role in human-modified neotropical forests. Biotropica, 46: 516-528. doi: 10.1111/btp.12126

Loeck, A.E. \& Grützmacher, D.D. (2001). Ocorrências de formigas cortadeiras nas principais regiões agropecuárias do Estado do Rio Grande do Sul. Pelotas: Universitária. 147 p.

Mariconi, F.A.M. As saúvas. São Paulo: Ceres. 1970. 167 p.

Mariconi, F.A.M., Zamith, A.P.L. \& Castro, U.P. (1961). Contribuição para o conhecimento da "saúva parda" Atta capiguara Gonçalves, 1944. Anais da Escola Superior de Agricultura Luiz de Queiroz, 18: 301-312. doi: 10.1590/ S0071-12761961000100020

Mariconi, F.A.M. (1966a). Nova contribuição para o conhecimento de saúvas do Estado de São Paulo. Anais da Escola Superior de Agricultura Luiz de Queiroz, 23, 399-415. doi: 10.1590/S0071-12761966000100035

Mariconi, F.A.M. (1966b0. Novas informações sobre a "saúva parda" Atta capiguara Gonçalves, 1944. Boletim da Escola Superior de Agricultura Luiz de Queiroz, 8 p.

Mariconi, F.A.M. (1970). As saúvas. São Paulo: Ceres. 167 p.

Meyer, S.T., Leal, I.R., Tabarelli, M. \& Wirth, R. (2011). Performance and fate of tree seedlings on and around nests of the leaf-cutting ant Atta cephalotes: Ecological filters in a fragmented forest. Austral Ecology, 36: 779-790. doi: 10.11 11/j.1442-9993.2010.02217.x

MMA - Ministério do Meio Ambiente. (2020). O Bioma Cerrado. Disponível em: https://www.mma.gov.br/biomas/cerrado/ (Accessed 19 May 2020).

Moreira, A.A., Forti, L.C., Andrade, A.P., Boaretto, M.A.C., Lopes, J. (2004). Nest Architecture of Atta laevigata (F. Smith, 1858) (Hymenoptera: Formicidae). Studies on Neotropical Fauna and Environment, 39: 109-116. doi: 10.1080/01650 20412331333756

Paula, H.S. (1956). Ocorrência de saúvas no Estado do Paraná. Boletim Fitossanitário, 6: 153-158.

Pereira da Silva, V. (1975). Contribuição ao estudo das populações de Atta sexdens rubropilosa Forel, e Atta laevigata (Fr. Smith) no Estado de São Paulo (Hym.: Formicidae). Studia Entomologica, 18: 201-250. 
Precetti, A., Nasato, A.C.M., Beltrame, G.J., Oliveira, J.E. \& Junior, M.P. (1988). Perdas de produção em cana de açúcar, causadas pela saúva mata pasto, Atta bisphaerica. Parte I. Boletim Técnico Coopersucar, 42: 19-26.

Souza, F., Broglio-Micheletti, F., Moura-Lima, M., Araújo, M.J.C. \& Delabie, J.H.C. (2009). Avaliação preliminar da mirmecofauna associada ao agronegócio floricultura com Heliconia spp. (Heliconiaceae) no estado de Alagoas, Brasil. Revista Caatinga, 22: 01-04.

Stephan, J.G., Wirth, R., Leal, I.R. \& Meyer, S.T. (2015). Spatially Heterogeneous Nest-Clearing Behavior Coincides with Rain Event in the Leaf-Cutting Ant Atta cephalotes (L.) (Hymenoptera: Formicidae). Neotropical Entomology, 44: 123-128. doi: 10.1007/s13744-014-0267-0

Teixeira, M.C., Schoereder, J. H. \& Mayhé-Nunes, A.J. (2003). Geographic distribution of Atta robusta Borgmeier
(Hymenoptera: Formicidae). Neotropical Entomology, 32: 719-721. doi: 10.1590/S1519-566X2003000400026

Thomas, J.C. (1990). Formigas cortadeiras: instruções básicas para o controle. Curitiba: EMATER. 32 p.

Urbas, P., Araújo, J.R.M.V., Leal, I.R. \& Wirth, R. (2007). Cutting more from cut forests: edge effects on foraging and herbivory of leaf-cutting ants in Brazil. Biotropica, 39: 489495. doi: 10.1111/j.1744-7429.2007.00285.x

Vieira-Neto, E.H.M, Vasconcelos, H.L. \& Bruna, E.M. (2016). Roads increase population growth rates of a native leaf-cutter ant in Neotropical savannahs. Journal of Applied Ecology, 53: 983-992. doi: 10.1111/1365-2664.12651

Wons, I. (1985). Geografia do Paraná: Física-humana-econômica. Curitiba: Ensino Renovado, 172 p.

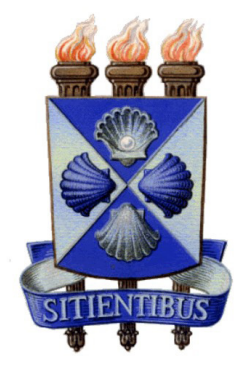

